第 3 丧

\begin{tabular}{|c|c|c|c|c|c|c|c|}
\hline 做字 & 7 & 8 & 9 & 10 & 11 & 12 & 13 \\
\hline 而 的 & SSW & ssw & $\mathrm{sw}$ & NW & WNW & NW & NNW \\
\hline 底 速 & 11.3 & 8.0 & 8.8 & 9.7 & 8.7 & 9.8 & 10.7 \\
\hline 降小䭪 & 1.3 & 2.1 & $0 \cdot 7$ & 1.5 & 0.7 & 0.0 & 0.1 \\
\hline \multicolumn{8}{|c|}{$=-5=$} \\
\hline 特 & 2 & 3 & 4 & 5 & 6 & 7 & 8 \\
\hline 風问 & $S E$ & $\mathbf{S E}$ & $\mathrm{ESE}$ & ESE & ESE & ESE & ENE \\
\hline 風 速 & 3.3 & 3.3 & 1.9 & 2.3 & 2.3 & 2.4 & 0.5 \\
\hline 隆水毁 & -- & $-\cdots$ & $\cdots$ & $\cdots$ & - & - & - \\
\hline
\end{tabular}

阻止される静が多い。

第3 表恪昭和 14 年12月14から15日にかけてのこ の間の關係を示した一例である。

この東風は割合に安定度の高い氣媿で歹り，風の息， 風向の振幅等何れも西風に比し甚しく小さい，この東 風の高さ快割合に低く、测風氮球の結果或は計算上か ら求められるが詳細福略する事とする。

\$7. 䊅語 以上季節風發達時に於ける石川縣地方 の降水の問題を娥報の參考の立場的調查して見た. 何問題は多及殘されてるる。より以上の研究は次の機 會を俟ちたい．

今包の調查から季節風に依る時雨的降水の有無は次 の樣な事から判別出來るであらう。

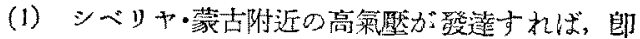
ち季節風の勢力が强ければ石川縣地方に時雨が訪れる:

(2) 朝鮮東海岸元山附近の氣溫が海上の㴋溫より も低けれは雨が降り，高ければ雨が降らない，實際的 には元山西郷等の氣温を照すれば聂的にも多少見當

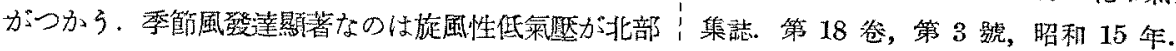

烝發に及㳊す風の影響につしで*

監見幸三，吉田進

\$1. 緒产 種々の狀沉の下に於ける水の蒸發量を：る場合に於ける或る時閜内の蒸登量を直接に測るとい

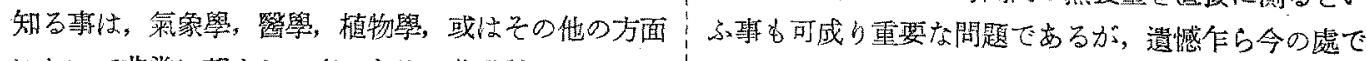

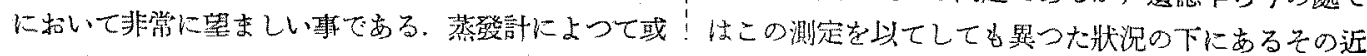

* K. Sioni and S. Yosida: Fffects produced by Wind on Evaporation. 
くの場所での其の時間內の蒸登量蚛必ずしも推知出來 ないのである.

岡田博士 ${ }^{(1)}$ によれば, 蒸發量は水の溫度、氣溫、氣 厣, 風速, 飽差, 日照, 空氣の溷罯度等の氣象要素の 他に土地の模樣によつても支配される. 從つて蒸發量 がこれらの要素に如何に關係するかが知られる事が望 ましい.上に擧げた要素の中，此較的重要な風速，鲍 差、氣㻺等の關倸に就ては古くから多くの公式が提出 されてるて，その中 Trabert の公式(2)が最す普通に

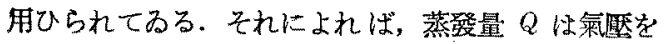
$P$, 空氣の溫度を $T^{b} K$, 飽差を $E-e$ とすれば,

$$
Q=C \frac{T}{P}(E-e) \sqrt{W}
$$

で與へられる，但し $C$ は上に擧げた諸要素によらな い常數であり、Wは風速である.

藤原呚授(3)は東京にける觀測材料を整理し，日月年 の本均值に對しては有效になるでき事を指摘されてる

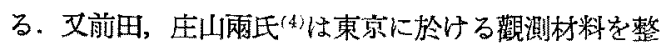
理して,Trabert口弪式における常數 $C か ゙$ 溫度に關倸 する揧を認め, 山本義一氏 放出の理論を應用して氣體運動論的に蒸發の公式を導 き, それに關聯して前田, 庄山兩氏の結果に言及し, 兩者が完全には一致しない事を認めた。よつて Trabert の歪式そのあの山吟味が必要であるとして，入

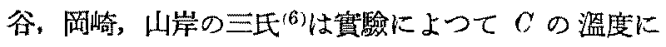
上る變化を調へ，閉め切つた空网に於ける測定に際し， 周圈の僅かな條件の違ひにより蒸發量の甚だ異る事を 認め, 更に約 $2 \mathrm{~m} / \mathrm{sec}$ の風速をおこした風洞內に蒸 發計を入れて測定した結果,

氟溫 $t^{\circ}{ }_{K} C$ K對し $C_{K}=C_{K}{ }^{\prime}\left(1-0.0142 t_{K}\right)$,

水溫 $t^{\circ}{ }_{m} C$ に對し $C_{M}=C_{x^{\prime}}\left(1-0.0167 t_{M r}\right)$

を得，前記の前田，它山兩氏の值 $C=C^{\prime}(1-0.0184 t)$ に近い值を得た.

我々は上記三氏の實驗と同樣な趣旨から，Trabert の公式を物理的な公式として吟味する立場に立つて三 氏の實驗に引續き，同じ測器を利用して風速による蒸 發量の變化を調べて見た。

(1) 岡由武松: 中央氮象臺歐交報告. 第 1 沿 (1904).

(3) 藤原吹本：氮像藮誌. 第 34 4年，第 1 號.

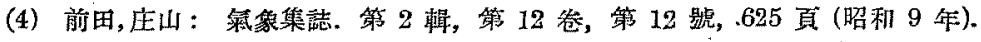

（5）山本義一：氣象集誌. 第 2 輯, ”第 14 兊, 第 8 號, 420 頁 (昭和 11 年).

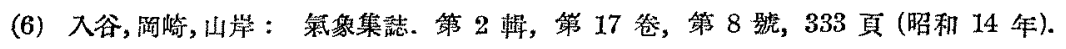

\$2. 䨘驗 蒸發量怯蒸發面の形, 大さ, 友び蒸發計 による事が考へられるから，此の實驗がそのま」他の 場合にあてはまるかどうかは疑問である。殊に空氣の 流れが幍される場合には先の程度により甚だしい差を 生ずる㲊れがある。. 此の䐝驗では風洞內の流れを成る べく筒さない樣に，蒸發訳の周圍に覆ひをかぶせ，器 壁が障害物にならぬ樣に努めた. 蒸發計は直俓約 10 $\mathrm{cm}$, 深さ約 $2 \mathrm{~cm}$ の硝子器で, これに深さ約 $1.5 \mathrm{~cm}$ 迄水を入れ，風洞のモーターの趣轉數をストロホスュ ープで䜠みながら調節して一定の風速を得，50 分閒 放置してその間の蒸發量を求めた. 測定前後に硝子器 に盐をして天科で重量を測り，測定中の蒸發は殆んど

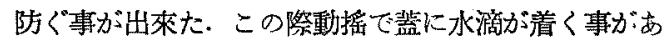
るから出來るだけ注意し，もしこれを認めれば，それ は放裹し惯驗をやり直した，風速と風洞モーターの䢙

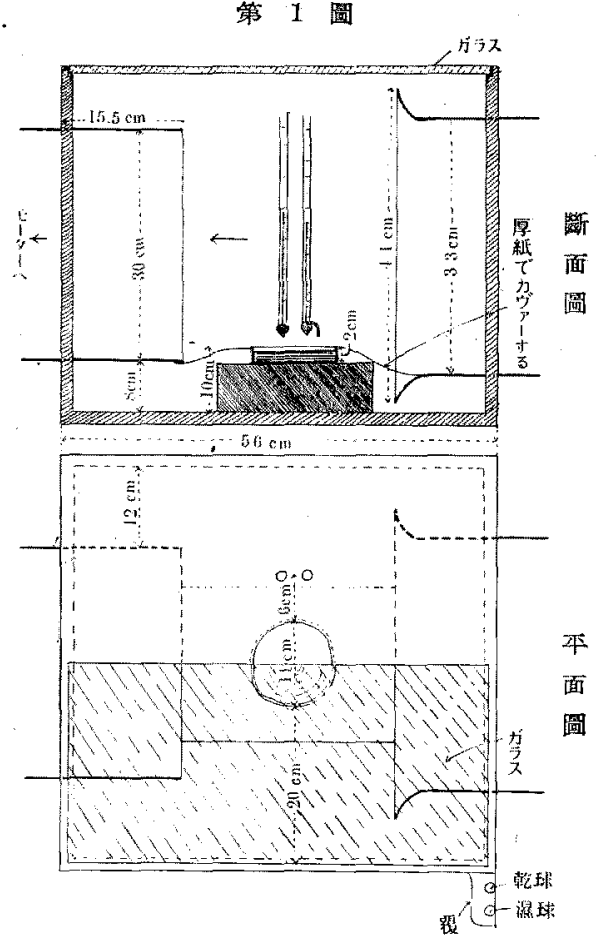

(2) Trabert: Met. ZS. 13 (1896) 261.

$$
-31-
$$




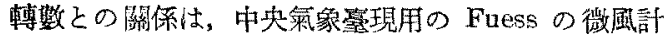
二種を並用して预め調べた。

水溫は參考の茎測定したが適當な寒暖計なく，中央 氣象囊で檢定した $1^{\circ} \mathrm{C}$ 目盛のむのを使用した。

㬎度の測定には中央氣象臺現用の乾濕球濕度計を用 ひ，これを風洞の外部皮び風洞內で蒸發計の近傍に置 いた．外部に置いた畭濕球に對しては，なるべく空㴋

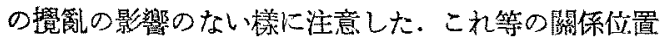
は，略:第 1 㗄の如くである.

§3. 完驗結果 宦驗結果としては別表の如き數值 を得た。

蒸發の公式: $Q=\frac{\left.T_{K^{\prime}} R-P\right)}{P}(1-a t) F(W)$,

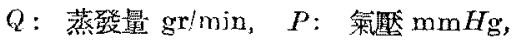

$E-e$ ：飽差 $\mathrm{mmHg}, t ;$ 氣溫 ${ }^{\circ} \mathrm{C}$,

$T_{K}$ : 氣溫 ${ }^{\circ} \mathrm{K} \quad T_{K}=273.18+t, W$ : 風速 $\mathrm{m} / \mathrm{sec}$, $a:$ 常數

に於いて $F(W)$ の形を知る事が本實驗の目的である 加ら、测定值から

$$
F(W)=Q P / T K(E-e)(1-a t)
$$

なる量を訫算した。

常數 $a$ としては入谷, 岡崎氏'敉の害驗結果を用ひ $a=0.0142$ とした.

一可の測定は 50 分間にわたつたが，その間氣暨の

第 2 回部
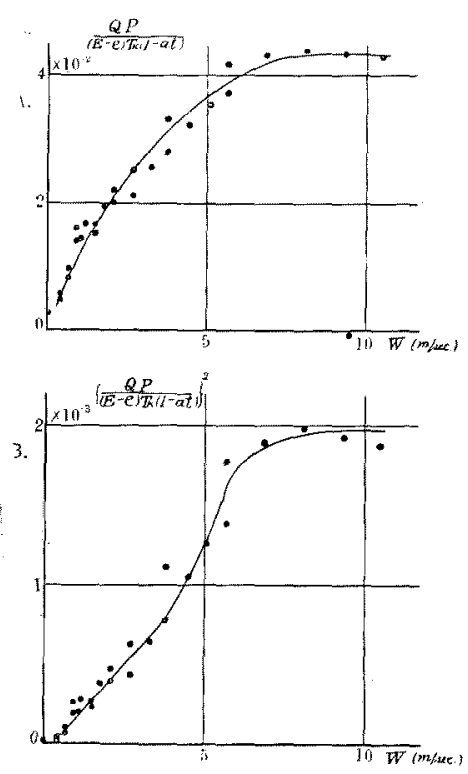

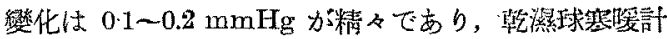
の示度は $0.1 \sim 0.2^{\circ} \mathrm{C}$ 變化した. 探用した溫度は 10 分

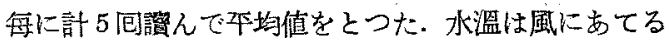
と常に 0.4 0.6 $6^{\circ} \mathrm{C}$ 下降し，10 20 分後には一定とな るのが認められた，之は入谷氏等も認められた所であ る.

榦港球の㴘度差から鲍差を求めるには，Angot の式 によつてるる埭象常用表を用ひた，畭濕球が一定風速 中にある時瀿度を示す避當な公式は未だないので，止 むを得ず風洞の外部においたりのの讀みを探用した。 但し氣溫は風洞內の寒暖計による.

風洞は東大物理敋空の直徑 $30 \mathrm{~cm} の \mathrm{Eiffel}$ 型咸洞 である。

第 2 圆 A は $Q P / T_{K}(E-e)(1-a t)$ を以教しと つたもの，同じく $\mathrm{B}$ はその自乘をとつだ尚のである.

\section{§4. 結果の捡討}

（1）精度 $Q P / T_{K}(E-e)(1-a t)$ なる量について, 最 る大きな誤差の原因となると思仕れるのは飽差 $E$-e である、然喛計の誤差は $0.05^{\circ} \mathrm{C}$ の程度であるから， $E-e$ の誤差は $1 \%$ 程度，從つてこの量に與へる哭差 も1\%程度となる、但し之は乾濕球の位置が全く適 虽であり，その上乾濕球の示度が Angot の公式に從 つて, 镇際の濕度に唹密に對㮣すると假定しての事で ある. 第一の點については，實際は乾濕球の示す濕度 は風洞の外部に於けるすのであるから，必ずしも水面 に流れて來る空氣のそれであるとは言へず，之は或は 更に大きな誤差の原因となるか子知れね。第二の點に ついては, 種々の場合に對して, 乾濕球濕度計々の屯 の上性質がくわしく調べられる事夌必要とする。いづ れにしてもこの照に關する誤差必相當大きいであらる 事は预想される。

他の量による誤差は上述のものに比し無視してよ い. 但し蒸發量を測る時, 天科名ら風洞への水の容器 を荤心゙際、容器の塧にあやまつて水被がついたりする と，意外に大きな誤盖を生ずる需がある。この事は既 述の如く充分注意したが，風速 $9.35 \mathrm{~m} / \mathrm{sec}$ に對寸る 測定值の一つが餘りに大にず゙るのは或はこれが原因 であるかも知れ奴。

風速については，モーターの何轉數を出來るだけ一 定に保つ樣に努力したが，5\% 程尿の誤差は㠰れ得な かつた. 然し，この誤差は正負打消し合ふ假向がある

（速すぎた後はお尗すぎるやらになるから）ので平均 


\begin{tabular}{|c|c|c|c|c|c|c|c|c|}
\hline $\begin{array}{cc}\text { 唒 } \\
W(\mathrm{~m} / \mathrm{sec})\end{array}$ & $Q\left(\frac{\mathrm{gr}}{\min }\right)$ & $P(\mathrm{~mm} \mathrm{H} g)$ & $\begin{array}{l}\text { 隿 洫 } \\
t\left({ }^{\circ} \mathrm{C}\right)\end{array}$ & $\begin{array}{c}\text { 乾球溫度 } \\
\left({ }^{\circ} \mathrm{C}\right)\end{array}$ & 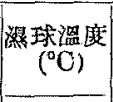 & $\begin{array}{c}\text { 水 盜 } \\
\left.{ }^{\circ} \mathrm{C}\right)\end{array}$ & $Q P /(E-e) T_{L}(1-a t)$ & $\left\{Q P /(E-e) T_{K}(1-a t)\right\}^{2}$ \\
\hline 0.00 & 0.00344 & 7620 & 27.50 & 27.45 & 25.60 & 27.3 & 0.0028 & 0.000008 \\
\hline 0.37 & 688 & 63.6 & 27.90 & 27.95 & 25.90 & 27.2 & 56 & 32 \\
\hline$"$ & 668 & 59.6 & 26.55 & 2670 & 24.25 & 26.1 & 48 & 23 \\
\hline 0.64 & 1018 & 60.4 & 26.85 & 27.15 & 25.20 & 26.1 & 96 & 92 \\
\hline 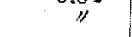 & 1336 & 59.6 & 26.95 & 27.05 & 24.20 & 24.7 & 81 & 66 \\
\hline 0.90 & 1398 & 63.0 & 27.30 & 27.45 & 25.75 & 26.5 & 139 & 193 \\
\hline "I & 1624 & 59.7 & 27.50 & 27.70 & 26.05 & 35.9 & 164 & 268 \\
\hline 1.03 & 1554 & 60.4 & 2685 & 2690 & 25.05 & - & 142 & 202 \\
\hline 1.16 & 1934 & " & 26.65 & 26.85 & 24.80 & 26.7 & 167 & 277 \\
\hline 1.48 & 1804 & 63.0 & 27.25 & 27.65 & 25.90 & 25.9 & 163 & 265 \\
\hline " & 2106 & 59.9 & 27.60 & 27.60 & 25.20 & 24.9 & 150 & 226 \\
\hline 1.76 & 2550 & ; & 27.20 & 27.35 & 25.10 & 25.4 & 194 & 377 \\
\hline 2.05 & 2304 & 630 & 27.55 & 27.85 & $25 \cdot 90$ & 25.7 & 199 & 395 \\
\hline y & 2678 & 60.0 & 26.80 & 26.90 & 24.80 & 24.8 & 220 & 482 \\
\hline 2.65 & 2652 & 63.0 & 27.95 & 28.20 & 26.10 & 25.6 & 208 & 434 \\
\hline . & 3358 & 60.0 & 2645 & 26.35 & 24.00 & 24.1 & 252 & 633 \\
\hline $3 \cdot 22$ & 3140 & 62.6 & 27.80 & 27,90 & 25.85 & 25.7 & 257 & 681 \\
\hline 3.80 & 3758 & " & 27.10 & 27.35 & 25.50 & 25.4 & 335 & 1123 \\
\hline & 3420 & 59.6 & 26.85 & 27.15 & 25.15 & 24.4 & 279 & 779 \\
\hline 4.43 & 4523 & 62.6 & 2810 & 28.45 & 2610 & 25.8 & 323 & 1046 \\
\hline 5.05 & 3662 & 59.6 & 26.80 & 27.00 & 24.80 & 23.9 & 355 & 1258 \\
\hline 5.60 & 4906 & 61.4 & 27.80 & 28.10 & 2615 & 25.6 & 421 & 1774 \\
\hline & 4526 & 59.6 & 26.70 & 26.80 & 24.65 & - & 372 & 1387 \\
\hline 6.83 & 5592 & 61.4 & 28.10 & 28.35 & 26.20 & 25.5 & 436 & 1908 \\
\hline 8.15 & 6098 & 60.9 & 28.20 & 28.45 & 26.15 & 25.4 & 444 & 1975 \\
\hline 9.35 & 5466 & 60.0 & 27.30 & 27.45 & 25.65 & 25.2 & 511 & 2613 \\
\hline$"$ & 6494 & 59.7 & 28.15 & 28.20 & 25.60 & 25.4 & 438 & 1915 \\
\hline 10.50 & 6990 & 61.9 & 27.75 & 27.80 & 25.00 & 243 & 433 & 1874 \\
\hline
\end{tabular}

としてはずつと少くなるであらう．容器中の水面の高：ものである．又堀口氏(3) は觀測の材料を統計的に整理 尼上る變化，即ち緣の效果も若へられるが，水の全 體の量は各測定につき略っ一定に保つたから、これは 一定と考へてよい. 叉富際水量の寡多による规則的な 樊化佉認められなかつた。

(2) 風速 6 7 m/sec 以上では $Q P / T_{\pi}(E-e)(1-a t)$ は，風速に閣俰せず一定となるやらに見える．上述の 如く風速による誤差が一番大きいと考へられるから， この部分は既に風速によらぬと考へれば， $6 \mathrm{~m} / \mathrm{sec}$ 以 下比比し，特に䛇差加少いや引に見えるのは別に偶然 の一致ではなく，當然であると思はれる．だ゙ 9.35 m/seck對する一つの測定のみがかけはなれてるるの は或は，前述の原因によるものであらうか.かくの如 く渐近值を有する事望は，その限界の風速に招いても， Horton(1)の結果と一致してるる.

(3) 6〜 $7 \mathrm{~m} / \mathrm{sec}$ 以下に於ては,最も普通に用ひられ るのは Trabert の式(2)であつて, $F(W / \infty \sqrt{W}$ とする して之を補足して $F(W) \infty \sqrt{W-C}$ とした．我々の結 果を見ると大體に扬いて堀口氏の公式と一致し， $C=$ $0.3 \sim 0.5 \mathrm{~m} / \mathrm{sec}$ となる. この值は堀口氏の得た， $C=3.4$ $\mathrm{m} / \mathrm{sec}$ に比すればかなり小であるが，夙口氏の式が紫 象觀測から矕納した氣象學的公式であるのに對し，我 々のものは風洞內の小さな室間內でなされた全く物理 的な公式である事を考へれば，不思議ではない。

(4) $F W(W) \sqrt{W}$ は蒸發の現象を單なる molecular

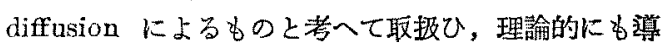
かれてるる. (但し之は空氣の流れが turbulent でな い場合で市つて, turbulence が坐ずる場合は，水蒸 氣が渦動によつて運ばれる事を考へねばならぬ. Sutton は之を取扱ひ, turbulent な大氣中の風の構造を 論じ, 更に之をか」る大氣中における蒸發に礁用した. (5)染によれば，圆形の面加らの蒸發速度は，F(W) のW

(1) R. E. Horton: Eng. News Record 78 (1917) 196.

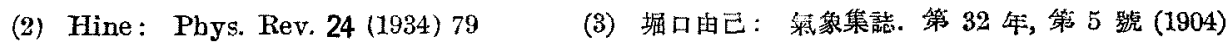

(4) H. Jeffreys: Phil. Mag. 35 (1918) 270: N. Szweikoski : Gerl. Beitr. Geophys. 24 (1929) 293

(5) O. G. Sutton: Proc. Roy. Soc. 146 A (1934) 
より 0〜1 に變じうる常數である. Suttonは,多くの 實驗結果から，滑らかな員筒邖で Reynolds 數の廣い 範圍にわたり $n=\frac{1}{4}$ でるるとし、從つて $F(W) \infty W^{0.58}$ 长得てるる，彼は Hine ${ }^{1)}$. Himus (2)等の筫驗結果が 之と良く一致する事学引用してるる。

我及の結果を $\quad F W(W-C)^{p}$

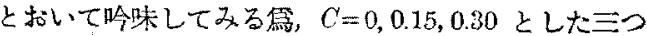
の場合につき, $Q P /(E-e) T_{K}(1-a t) \sim W$ を logarithmic scale K書导，各:の場合に $p$ を圆上から求めて みると，

$\begin{array}{lc}C & p \\ 0 & 0.54 \sim 0.73 \\ 0.15 & 0.49 \sim 0.62 \\ 0.30 & 0.46 \sim 0.62\end{array}$

となる。

印ち、 $p$ は 0.5 (堀口，Trabert) 或はそれより稍:
大であるが 0.78 (Sutton) よりは相當小さい。

此の實驗は，東京帝大理學部物理學科後期課程に打 ける氣家學演習として行はれたものであつて，藤原先 生、小平先生の懇切な御指導を賜つた，終りにのぞん で著者等の深甚なる謝意を兩先生に䋦げたいと思ふ。

附記 3 月 8 日の氣象學會に执ける譵演に際して, 我々の實驗に括いて飽差の計算に際し，最大蒸氣張力 を堂氣の溫度に對するものを取つたが，若しそれを水

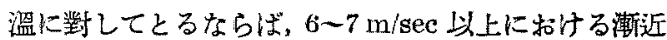
值をとる現象は除加れるのではないかと云ふ議論があ つたこれについて材料を再調查したが，何分水溫測 定の精度が低いので，結果は却つて不規則になつてし まふ. Trabert の式の成立から考へるならば, $E$ とし ては水溫に對する最大蒸氣歷をとるのが妥當とも考へ

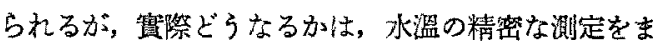
つて言ひ得る事であらら。

\section{大日本気象學會講演會}

四月月次會 昭和 15 年 4 月 12 日（金）中央氣家 臺構內中村記念館に於て，午後 4 時 10 分開演， 講演 5.

座長 侁藤幹事 出席者 30 名

1. 大後美保君：馬鈴整の收量々氯像との關係（第 一報）日本主要農作物の收量と氭象との關倸 に閶士る研究 第三號

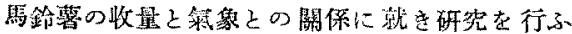

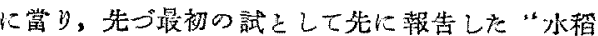
の收量と減象との關保”を全く同一の坊法により

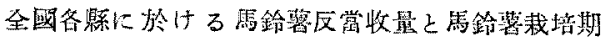

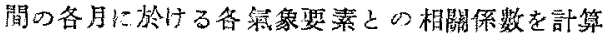

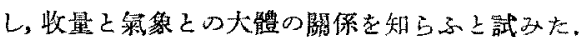

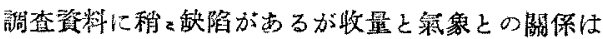
東部地方々西部地方とで反数心關保のある等を知 り得长。

2. 中原孫吉君：植物葉中に含まるつクロ、フキ

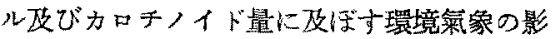
䉭に就いて (第一報)

ナソダタの籸莱期に近い9 月下旬より11月上 旬落葉期頃迄心莱中のタロ、フ年心䝘びカ口チ， イド量の環堷氣象による戀化を調べたものである。

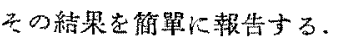

3. 中原孫吉君：櫻の 開花期の 地理的 分布に就い $\tau$

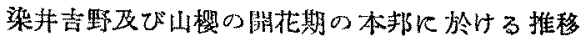
狀態芝謂查せるものであり，染井吉野 110 ケ所,

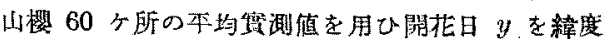

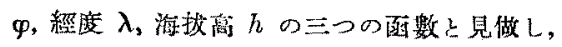
$y=a+b\left(\varphi-35^{\circ}\right)+c\left(\lambda-135^{\circ}\right)+d h$ の式を䧟用し，最小自乘法を用ひて $a, b, c, d$ の 常数決定した。

4. 山烟義宗，川本敏夫君：本邦附近の低氣的淮路 の季篰變化

本邦附近の低氮郍の 進行方向及び速度が季篩に

(1) Hine: Phys. Rev. 24 (1924) 79.

(2) Himus: Inst. Chem. Eng., Conference on Vapour Absorption and Adsorption (1929). 